\title{
A fonológiai tudatosság és a mentális lexikon fejlettségének számítógép-alapú mérését lehetővé tevő tesztrendszer kidolgozása
}

A 21. századi társadalmi és gazdasági fejlôdés alapját az irni és olvasni tudó emberek jelentik, ezért minden társadalom számára

stratégiailag meghatározó állampolgárainak megfeleló szintú olvasási képessége. A mindennapi életben, a munkaerópiacon való sikeres boldoguláshoz elengedhetetlen az olvasási képesség mint a

tudás-és információszerzés alapvetố eszközének (Molnár és B. Németh, 2006) megfeleló szintú múködése. A tömeges oktatás egyik legnagyobb problémája, hogy a tanulók sokfélék, ellenben a tanitásuk

hasonló módon történik. Ennek a problémának a megoldása a személyre szabott oktatás, melynek alapja a rendszeres, konkrét értékelés. A számitógépes (online) tesztelés jelentôs segitséget nyújthat az individualizált tanuláshoz és tanitáshoz (Csapó, Molnár,

Pap-Szigeti és R. Tóth, 2009). A diákok közötti hátrányok kiegyenlitésével nagy hozamot lehet elérni (Csapó, Nikolov és Molnár, 2011, idézi Molnár, 2015b). A korai intervenciós programok elemzési

rátái egyértelmúen azt mutatják, hogy az oktatási befektetések megtérülése akkor a legmagasabb, ha az a korai életkorra fókuszál. A közoktatás késóbbi szakaszaiban már csak jelentós befektetésekkel lehet a kialakult lemaradásokat behozni (Molnár, 2015a, b).

A tanulói fejlődés segítése érdekében rendszeres, konkrét mérés-értékelésre van szükség (Csapó, Molnár, Pap-Szigeti és R. Tóth, 2009). Ennek alapfeltétele, hogy a pedagógusok eszköztárában legyen olyan mérőeszköz, amely alkalmas a képességszint gyors, pontos megállapítására a helyes fejlesztési irányvonal meghatározása céljából, s egyben alkalmas a longitudinális mérések elvégzésére is, a fejlődés mértékének megállapítása és a fejlődési irányvonal szükséges változtatása érdekében. A fenti cél elérése érdekében a mérés-értékelés tradicionális modelljeinek alkalmazását nagy időráfordítással s jelentős anyagi befektetéssel lehet megvalósítani.

A 21. század igényeihez alkalmazkodva a tömeges felmérések alkalmazása során a hagyományos papír-ceruza ('Paper and Pencil', PP) tesztek helyét egyre inkább a számítógép-alapú tesztelés (Computer Based Assessment, CBA) veszi át. A nemzetközi empirikus adatokra támaszkodó mérés-értékelési programok közül a PISA 2006-os vizsgálatában már szerepelt számítógépes felmérés, a természettudományi tudás területén. A PISA 2009-es felmérésben pedig, a szövegértés területen, már önálló rész- 
skála volt. A PISA 2012-es felmérésben a nyomtatott tesztfeladatokkal párhuzamosan számítógép-alapú teszteket is kitöltöttek a tanulók szövegértés és matematika területén. A 2016-os PIRLS vizsgálat is megújul. Az ePIRLS-ben már mérni fogják a tanulók online olvasásának fejlettségét. Ezzel az innovatív értékelési eljárással mérhetővé és összehasonlíthatóvá válik, hogy az egyes országok mennyire sikeresen készítették elő a negyedik osztályos diákokat az online, digitális szövegek olvasására, értelmezésére (Mullis és Martin, 2015). Hazai viszonylatban a SZTE OK munkatársai kiépítették az eDia online segítő-fejlesztő diagnosztikus mérési-értékelési rendszert, melynek főbb mérési területei az olvasás-szövegértés, a matematika és a természettudomány. A rendszer az 1-6. osztályos tanulók mérésére alkalmas teszteket tartalmaz (Csapó és Molnár, 2013). A feladatfejlesztés egy háromdimenziós modellen alapul, az oktatás legfőbb céljait tükröző tartalmi keretek között (Csapó és Csépe, 2012). A feladatsorok összeállítása a háromdimenziós modell alapján három szempont szerint történt. Mindegyik területen a feladatok egyharmada a fejlődés pszichológiai sajátosságait (értelmi, gondolkodási képesség) méri. A feladatok másik része az iskolai keretek között megszerezhető tudás alkalmazásának kepésségét vizsgálja, a harmadik rész pedig a szaktudományok által igazolt, diszciplináris tudás mérésére alkalmas (Molnár, 2015a).

A számítógép-alapú tesztelés bevezetésével rövidtávon a kutatók anyagi megtakarítást, a tesztelésre fordított idő csökkenését várják, illetve pontosabb információkat mind a mérés, értékelés területéröl, mind a tanulók feladatvégzéséről. Hosszú távú jelentőségét a multimédiás elemekkel gazdagított új típusú itemek adhatják (Csapó, Molnár és $R$. Tóth, 2008).

Előnyeként említhető az objektív adminisztráció (független a vizsgálatvezető személyétől, kizárja az adminisztrációs hibát, mivel automatikus a válaszok rögzítése); a gyors visszajelzés, az azonnali pontozás; a tesztfelvétel szintjén a kivitelezés, a változtatás, a fejlesztés olcsóbb; lehetőség van multimédiás elemek alkalmazására is (pl. hang, kép, videó); vagy a gyakorló rendszereken belül kisegítő utalások, útmutatások alkalmazására (Domino és Domino, 2006; Wang, Jiao, Young, Brooks és Olson, 2008; Csapó, Molnár és Nagy, 2014). Mindezek mellett lehetőséget biztosít az egyéni képességekhez igazodó adaptív tesztek alkalmazására, ahol minden személy a számára leginkább diagnosztikus erővel rendelkező feladatot kapja. Ezzel az eljárással elkerülhetővé válik, hogy az alacsonyabb képességü diákokat a számukra nehéznek bizonyuló feladatokkal frusztráljuk, valamint hogy a magasabb képességü tanulók a könnyebb feladatok megoldásával töltsék a tesztelésre biztosított idejüket (Csapó, Molnár és R. Tóth, 2008; Magyar és Molnár, 2015). A pedagógiai mérésekben meghatározó előny, hogy a technológia segítségével új perspektívából is megismerhetjük a kognitív képességek müködésének és fejlődésének folyamatát (Csapó, Molnár és Nagy, 2014), például a tanulás sikerességét befolyásoló olvasási vagy információ-feldolgozó stratégiának megismerésére alkalmasak a szemmozgás-követéses vizsgálatok (Steklács, 2014).

A számítógépes tesztelés bevezetését az infrastrukturális fejlesztések is elősegítik hazánkban. Molnár és Pásztor-Kovács (2015) áttekintette a hazai általános és középiskolák informatikai eszközparkját és hálózati kapacitását. A kapott eredmények alapján megállapították, hogy a 2011-es (bővebben: Tóth, Molnár és Csapó, 2011) adatfelvétel óta jelentősen csökkent a tanulói létszám mint prediktív faktor ereje az egy före jutó számítógép-aránnyal összefüggésben. Az iskolák többsége (iskolatípustól függetlenül) egyszerre egy osztály online mérését képes megvalósítani a település típustól függetlenül. Ez megfelelö alapot biztosít a kis téttel bíró értékelési rendszerek átalakításához.

Molnár és Magyar (2015) a pedagógusok és a diákok szemszögéből vizsgálta a számítógépes tesztelés elterjedésének kérdését. Azok a diákok, akik már több online tesztet is megoldottak, többségében preferálták az elektronikus tesztek elterjedését. Kimagasló a 
pedagógusok attitüdje, mivel a megkérdezettek 90 százaléka nyitott a változtatásra mind a kis téttel bíró, mind a redszerszintü mérések esetében is.

A pedagógiai folyamatokban alkalmazható hagyományos papír-ceruza és a számítógép-alapú tesztek egyenértéküségének kérdésével már 1997-ben Singleton is foglalkozott a fonológiai tudatosság fejlettséget mérő CoPS teszt fejlesztése során. A CoPS (Cognitive Profiling System; Singleton, Thomas és Leedale, 1996) egy szabványosított számítógépes pszichometriai rendszer, 4-8, 11 éves gyermekek kognitív erősségeinek és gyengeségeinek azonosítására szolgáló eljárás. Iskolába lépéskor alkalmas szürőeszközként való alkalmazása. Felfedi azokat a problémás területeket, amelyek hosszú ideig rejtve maradnának, ezzel elkerülhetővé válik a későbbi tanulási nehézségek kialakulása. Kilenc szubteszt közül egy méri a fonológiai tudatosság fejlettségét a ritmus és alliterációk felismerésével, valamint egy szubteszt az auditív diszkriminációs képességet a fonémák szintjén. A standardizálás során $(\mathrm{n}=800)$ a valós predikciós arány 96 százalékos, a negatív arány 16,7 százalék és a fals pozitív arány 2,3 százalék. A hallási diszkrimináció és a fonológiai tudatosság eredményezte a legmagasabb korrelációs együtthatót az olvasás fejlődésével (Singleton, 1997).

A számítógép-alapú fejlesztések elkezdődtek a mentális lexikon diagnosztizálásának területén is. A nemzetközi kutatások közül kiemelnénk Maguire, Knobel, Knobel, Sedlacek és Piersel (1991) összehasonlító vizsgálatát, melyben 112 általános iskolás tanuló passzív szókincsét vizsgálták a Peabody Picture Vocabulary Test - Revised (PPVT-R) hagyományos papíralapú és számítógép-alapú teszttel egyaránt. A sztenderd és a módosított teszt pozitív korrelációja alapján $(\mathrm{r}=0,76)$ megállapították, hogy a számítógép-alapú teszt alkalmas a klinikumi használatra, finom diagnosztikai célból (Maguire, Knobel, Knobel, Sedlacek és Piersel, 1991). A teszt elterjedésével, s következők kidolgozásával, elérhető lenne, hogy egy speciális végzettségü diagnoszta egy időben több személy (akár egy osztály) passzív szókincsét is fel tudja mérni, minimális hibázási számmal, a szubjektivitás elkerülésével. Hasonlóképpen, Wilson, Thompson és Wylie (1982) magas korrelációt $(\mathrm{r}=0,84)$ állapítottak meg a Mill Hill szókincs-teszt számítógépes és hagyományosan felvett tesztváltozatainak eredményei között.

A hazai pedagógiai gyakorlatban rendszeresen alkalmazott DIFER teszt (Nagy, Fazekasné Fenyvesi, Józsa és Vidákovich, 2002) öt résztesztjének (beszédhanghallás, relációs szókincs, elemi számolási készség, tapasztalati következtetések, tapasztalati összefüggés-megértés) számítógépes adaptálása a közelmúltban megvalósult (Csapó, Molnár és Nagy, 2014). A számítógép-alapú teszt az eDia (Csapó és Molnár, 2013) online felületen került kiközvetítésre első osztályos tanulók számára a tanév elején. A kutatás célja a médiumhatás vizsgálata volt, a két tesztkörnyezet összehasonlításával. A vizsgálati eredmények igazolták, hogy az online résztesztek megbízhatósági mutatója magasabb, mint a hagyományos részteszteké. A legnagyobb javulás a beszédhanghallás részteszt esetében volt megfigyelhető. A tradicionális környezetben is magasnak számító 0,889 megbízhatósági mutató (Cronbach- $\alpha$ ) a számítógépes környezetben 0,938-as (Cronbach- $\alpha$ ) értékével kiemelkedően magas volt, ami az egységes, jó minőségü hangingernek köszönhető. A kétféle teszttípuson elért átlagteljesítmények összehasonlítása csak a beszédhanghallás részteszten mutatott szignifikáns különbséget a fiúk és lányok teljesítménye között. A lányok jobb eredményt értek el, mit a fiúk $\left(\mathrm{M}_{\text {lány }}=86,37\right.$ százalék, $\mathrm{SD}_{\text {lány }}=12,76$ százalék; $\mathrm{M}_{\text {fiú }}=80,40$ százalék, $\mathrm{SD}_{\text {fiú }}=18,03$ százalék, $\mathrm{t}=3,94, \mathrm{p}<001)$. A mérési invariancia kérdése két szubteszt esetében nem merült fel: a beszédhanghallás és a relációs szókincs területén, mivel a feladatok a két tesztkörnyezetben hasonlóak voltak.

A tanulmányban ismertetett kutatást két pilotvizsgálat előzte meg (ld. Szili, 2013; Szili és Pásztor, 2013), melyekben egy-egy terület itemeinek vizsgálatát végeztük. Az első pilotvizsgálat során a fonológiai tudatosság és a mentális lexikon fejlettségét mérő tesz- 
tek müködését vizsgáltuk. A második pilotvizsgálatban pedig a szemtől szembeni kapcsolatot igénylő teszt és a számítógép-alapú teszt müködését hasonlítottuk össze. A kutatások eredményei alapján válogattuk ki, valamint fejlesztettük tovább feladatainkat.

\section{Célok, kutatási kérdések}

Kutatásunk célja az olvasás sikerességét nagymértékben meghatározó fonológiai tudatosság és mentális lexikon fejlettségének mérésére alkalmas online teszt kidolgozása volt. Kutatási kérdéseinket két célból fogalmaztuk meg: (1) a korábbi, szemtől szembeni kapcsolatot igénylő feladatok átkonvertálhatóak-e számítógépes környezetbe, (2) kialakítható-e osztálytermi környezetben megbízhatóan müködő olyan tesztrendszer, mely alkalmas a fonológiai tudatosság és a mentális lexikon fejlettségének megítélésére.

A kutatás a vizsgált korosztály (1-3. évfolyam) és szerkezetének tekintetében is hiánypótló, mivel a számítógép-alapú tesztelés főleg az idősebb korosztály esetében elterjedt, s az általunk vizsgált területek ilyen mértékü komplexitása nemzetközi szinten is csak egy-egy esetben valósult még meg, haza viszonylatban pedig még egyáltalán nem.

\section{Minta}

A nagymintás adatfelvétel 2014. március és április hónapjában történt 1-3. osztályos tanulók részvételével. A három tesztváltozatot közel azonos arányban közvetítettük ki a diákok részére $\left(\mathrm{n}_{\mathrm{A}}=495 ; \mathrm{n}_{\mathrm{B}}=492 ; \mathrm{n}_{\mathrm{C}}=528\right)$. A minta évfolyam szerinti eloszlását az 1 . táblázat tartalmazza. A vizsgálatba bevont tanulók egy megyeszékhelyü város 12 általános iskolájának tanulói.

1. táblázat. A minta évfolyam szerinti eloszlása

\begin{tabular}{|l|c|c|c|}
\hline \multirow{2}{*}{ Évfolyam } & \multicolumn{3}{|c|}{$N\left(f^{\prime \prime}\right)$} \\
\cline { 2 - 4 } & $A$ & $B$ & $C$ \\
\hline 1. & 184 & 165 & 172 \\
\hline 2. & 161 & 168 & 169 \\
\hline 3. & 150 & 159 & 187 \\
\hline
\end{tabular}

\section{A vizsgálat során alkalmazott eszközök bemutatása}

A mérőeszköz összeállításakor meghatározó kérdés volt, hogy a feladatok milyen szavakból épüljenek fel. A szóanyag kiválasztásában a Nagy József (2004) által alkalmazott 4000 szót vettük alapnak, melyet a szóolvasás készségét mérö tesztje tartalmaz. Ezekből a szavakból válogattuk ki azokat a főneveket, igéket, mellékneveket, határozószavakat, amelyeket alkalmasnak ítéltünk a mérőeszköz szókészletének kialakítására. Ezután a szavakhoz megfelelő képanyagot kerestünk. Egy-egy szóhoz több képet is válogattunk, amelyeket első osztályos tanulókkal megneveztettünk. A mérőanyagba azok a képek kerültek, amelyeket a csoportban minden diák felismert, azonosítani tudott.

A tesztfeladatok összeállításában elsődleges szempont volt, hogy olyan tesztrendszert állítsunk össze, amelyek az olvasástanulás kezdő fázisához szükséges fonológiai tudatosság és mentális lexikon fejlettségét diagnosztizálhatja. Mivel ilyen típusú tradicionális eljárást nem ismertünk, ezért több vizsgálóeljárást ötvöztünk (2-3. táblázat). 
Szili Katalin: A fonológiai tudatosság és a mentális lexikon

2. táblázat. A fonológiai tudatosság fejlettségét mérő feladatsor összeállitásban alkalmazott mérési eljárások

\begin{tabular}{|c|c|}
\hline Területek & Alkalmazott mérési eljárás \\
\hline Fonológiai szint & $\begin{array}{l}\text { BISC (Jansen, Mannhaupt, Marx és Skowronek, 1999) } \\
\text { TOPA (Test of Phonological Awareness; Torgesen és Bryant, 1994) } \\
\text { CoPS (Cognitive Profiling System; Singleton, Thomas és Leedale, 1996) } \\
\text { Fonológiai Tudatosság Teszt (Jordanidisz, 2009) } \\
\text { Hangtani (fonológiai) tudatosság teszt (Lörik és Májercsik, 2015) }\end{array}$ \\
\hline Fonémaszint & $\begin{array}{l}\text { PAT (Phonological Awareness Test; Robertson és Salter, 1995) } \\
\text { CTOPP (Comprehensive Test of Phonological Processing; Wagner, Torgensen } \\
\text { és Rashotte, 1999) } \\
\text { CoPS (Cognitive Profiling System; Singleton, Thomas és Leedale, 1996) } \\
\text { DIFER (Nagy, Fazekasné Fenyvesi, Józsa és Vidákovich, 2002) } \\
\text { Fonológiai Tudatosság Teszt (Jordanidisz, 2009) } \\
\text { Hangtani (fonológiai) tudatosság teszt (Lörik és Májercsik, 2015) }\end{array}$ \\
\hline
\end{tabular}

A fonológiai tudatosság fejlettségét tág értelemben alkalmaztuk. Így a fonológiai és a fonetikai szinthez tartozó müveletek széles spektrumát határoztuk meg vizsgálati céljaink megvalósításában. A fonológiai szinten a szavakkal és a szótagokkal való manipulálást, a fonetikai szinten pedig a hangokkal való müveletvégzést értettük (Csépe és Tóth, 2008; Goswami, 2006; Konza, 2011). A mentális lexikon fejlettségének megítélését a szemantikai müveletek síkjában értelmeztük, ezért a receptív és expresszív szókincs vizsgálatára alkalmas képfelismerési és képmegnevezési feladatokat nem alkalmaztuk. Választásunk négy olyan területre esett, amelyek meghatározóak a mentális lexikon szerveződésében (Lukács, Pléh, Kas és Thuma, 2014), s vizsgálatuk az angol nyelvterületen és a hazai pedagógiai gyakorlatban is elfogadott. Ez a négy terület a föfogalmak, a rokon értelmü kifejezések, az ellentétes kifejezések és a téri relációkat jelölő kifejezések.

3. táblázat. A mentális lexikon fejlettségét mérö feladatsor összeállitásban alkalmazott mérési eljárások

\begin{tabular}{|l|l|}
\hline \multicolumn{1}{|c|}{ Területek } & \multicolumn{1}{c|}{ Alkalmazott mérési eljárás } \\
\hline Föfogalmak & $\begin{array}{l}\text { The WORD Test 3 Elementary (Bowers, Huisingh, LoGiudice és Orman, 2014) } \\
\text { Nyelvi teszt (Lörik és Májercsik, 2015) }\end{array}$ \\
\hline Rokon értelmü kifejezések & $\begin{array}{l}\text { Synonym Vocabulary (Salthuse, 1993) } \\
\text { The WORD Test 3 Elementary (Bowers, Huisingh, LoGiudice és Orman, 2014) }\end{array}$ \\
\hline Ellentétes kifejezések & $\begin{array}{l}\text { Antonym Vocabulary (Salthuse, 1993) } \\
\text { The WORD Test 3 Elementary (Bowers, Huisingh, LoGiudice és Orman, 2014) } \\
\text { Nyelvi teszt (Lörik és Májercsik, 2015) }\end{array}$ \\
\hline Téri relációk & DIFER (Nagy, Fazekasné Fenyvesi, Józsa és Vidákovich, 2002) \\
\hline
\end{tabular}

A mérőeszköz a fonológiai tudatosság és a mentális lexikon fejlettségét vizsgálja. A mentális lexikon fejlettségi szintjének mérését célzó teszt négy területen vizsgálja a szavak értelméhez való hozzáférést: (1) főfogalmak, (2) rokon értelmü kifejezések, (3) ellentétes kifejezések, (4) téri relációs szókincs. A fonológiai tudatosság teszt a fonológiai és a fonémaszinten belül három szinten méri a szavak belső szerkezetéhez való hozzáférésének képességét: (1) beszédhangok, (2) szótagok, (3) szótagszerkezet. A fonémaszinten öt területet mér: (1) beszédhang-izolálás, (2) beszédhang-szintézis, (3) beszédhang-analizálás, (4) hosszú-rövid beszédhang azonosítása, (5) beszédhang-manipuláció. A fonológiai szinten négy területet mér: (1) szótag-elhagyás, (2) szótagszegmentálás, (3) rímfelismerés szavakban, (4) rímfelismerés mondatok végén.

A tesztfejlesztés során három azonos felépítésü tesztváltozatot készítettünk $(\mathrm{A}, \mathrm{B}, \mathrm{C})$. Mindegyik teszt 81 itemből állt, a mentális lexikon fejlettségét vizsgáló 4 terület $9-9$ ite- 
met (összesen 36), a fonológiai tudatosságot vizsgáló kilenc terület 5-5 itemet (összesen 45 item) tartalmazott (1. ábra).

A három tesztváltozatot horgonyitemek kötötték össze, hogy az elemzések során közös skálán tudjuk jellemezni mind a tesztrendszer feladatait, mind a mintában lévő különböző tesztet megoldó diákok képességszintjeit. A horgonyzási struktúra kidolgozása során a stabil horgonyzás biztosítása érdekében elsődleges szempont volt, hogy mindegyik mérési terület itemszámának harmada szerepeljen kettő vagy mindhárom tesztváltozatban (Molnár, 2013). Így összesen 48 horgonyitem szerepelt a 164 itemből álló tesztrendszeren belül: a fonológiai tudatosság területén 23 item, a mentális lexikon területén pedig 25 item. A horgonyitemek a tesztekben hasonló helyen szerepeltek. A tesztek erős horgonyzását ('fat anchor') biztosította az a 24 item, amely mindhárom tesztváltozatban szerepelt. Szintén 24 item alkotta a páronkénti horgonyzás alapját (A-B, A-C, B-C; 2. ábra).

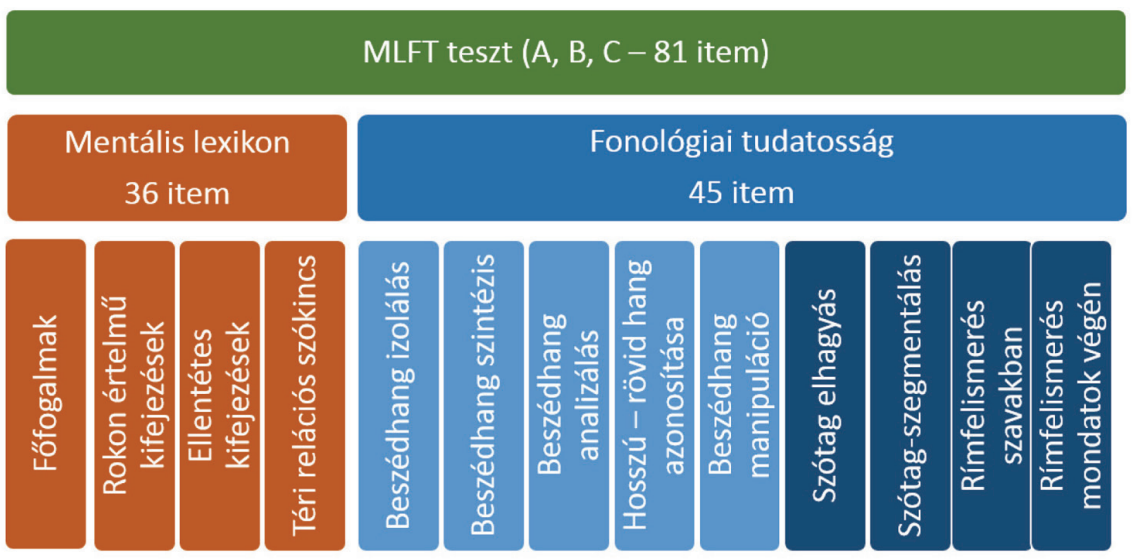

1. ábra. A Mentális Lexikon és Fonológiai Tudatosság fejlettségét mérö teszt (MLFT) struktúrája

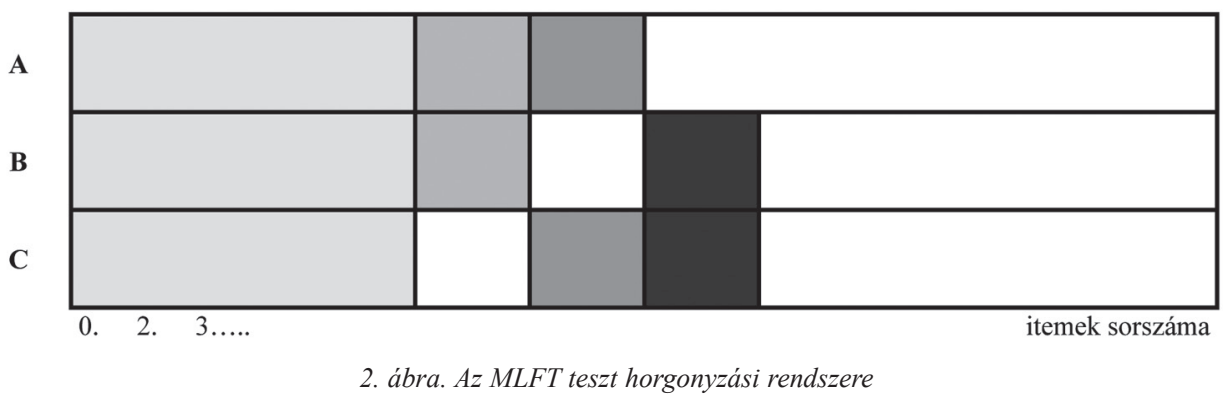

A tradicionális vizsgálati metódus számítógépes környezetre való adaptálása teljes mértékben nem lehetséges, mivel hangfelvételre és azok elemzésére a jelenlegi rendszer még nem alkalmas. A feladatok megoldása során a tanulóknak nem kellett kimondania a szót, szótagot vagy hangot, hanem képre való kattintással válaszoltak (3-4. ábra). 
Instrukció: Melyik kép nevét hallod? Kattints a megfelelö képre! Hallott hangsorozat: $\mathrm{p}-\mathrm{a}-\mathrm{p}-\mathrm{a}-\mathrm{g}-\mathrm{a}-\mathrm{j}$

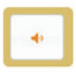

Melyik kép nevét hallod?

\section{Kattints a megfelelö képre!}

$+$
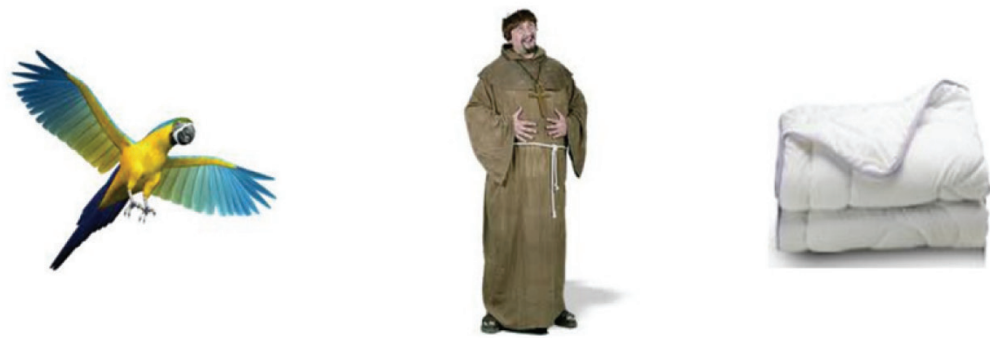

- Következö

3. ábra. Fonológiai tudatosság mintafeladata

Instrukció: Ezek az emberek mennek. Mondhatom úgyis, hogy jönnek?

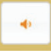

* Ha igen, kattints a fekvö macskára, ha nem, kattints az álló macskára!
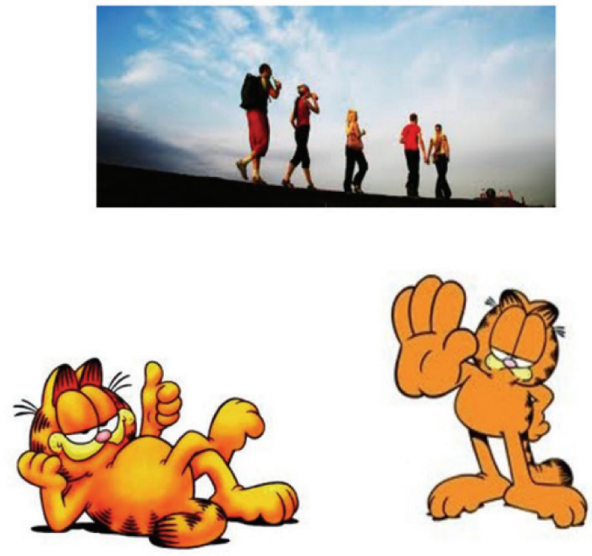

4. ábra. Mentális lexikon mintafeladata 


\section{Eljárások}

A tesztek az eDia rendszerén belül (Molnár és Csapó, 2013) kerültek kidolgozásra és felvételre. A tanulók saját intézményük számítógépes termében online töltötték ki a teszteket. A tesztek kitöltésére egy tanóra (45 perc) állt a tanulók rendelkezésre. A segítő pedagógusok részletes útmutatást kaptak írásban - és igény szerint szóban is - a tesztek céljáról, feladatairól és a lebonyolítás mentéröl. A gyermekekkel lévő pedagógus a mérési azonosító beírásában nyújtott segítséget, a feladatok megoldásban nem.

A kutatási eredményeket klasszikus tesztelméleti módszerekkel és valószínűségi tesztelmélet alkalmazásával elemeztük. A klasszikus tesztelméleti elemzéseket az SPSS program, a valószínüségi tesztelméleti elemzéseket pedig a ConQuest program alkalmazásával végeztük, az egyparaméteres Rasch-modell segítségével. Az adatok elemzése során a tesztek technikai müködését, az item jellemzőket vizsgáltuk. A horgonyitemekkel ellátott és az adaptív teszt megbízhatóságának jellemzésére a valószínüségi tesztelmélettel számítható WLE személy-szeparációs reliabilitásmutatót alkalmaztuk. Az item- és személyparamétereket a valószínüségi tesztelmélet képességskálaként (logitskála) értelmezi, ezért logitértékekkel jellemeztük az itemek viselkedését.

\section{Az eredmények bemutatása}

Az eredmények általánosíthatóságára tesztrendszer szintjén a WLE személyszeparációs reliabilitásmutatót, míg tesztszinten a Cronbach- $\alpha$ mutatót használtuk. A három tesztváltozat megbízhatósági mutatója külön-külön közel azonosnak bizonyult (Cronbach- $\alpha=0,92-0,93$ ), aminek következtében a WLE személyszeparációs reliabilitásmutató is 0,93 volt. A reliabilitásmutatók alapján megállapítható, hogy a három tesztváltozat megbízhatóságát tekintve teszt- és tesztrendszer-szinten is alkalmas az 1-3. évfolyamos tanulók fonológiai tudatosságának és a mentális lexikon fejlettségének mérésére.

A személy/item-térképek képességeloszlási görbéje alapján a minta közelít a normál eloszláshoz, azonban a középértékek mindhárom tesztváltozatban a 0 , azaz egy modellált populáció átlagos képességszintje felett vannak (5-7. ábra). A minta tagjainak átlagos képességszintje 0 és $+2,5$ logitegység között van, de képességszint tekintetében -2 és -3 logitegység szintü diákok is vannak a mintában, azaz az egyes tanulók között jelentős különbségek vannak e területen. A leggyengébb és legmagasabb képességszintü diákok között 6 logitegységet meghaladó különbséget tapasztalunk (4. táblázat).

4. táblázat. WLE képességparaméter A, B, C teszt

\begin{tabular}{|l|c|c|c|c|c|}
\hline \multicolumn{1}{|c|}{ Teszt } & Középérték & Szórás & Minimum érték & Maximum érték & Skála terjedelme \\
\hline $\mathrm{A}$ & 0,69 & 1,06 & $-2,37$ & 3,87 & 6,24 \\
\hline $\mathrm{B}$ & 0,61 & 1,00 & $-4,34$ & 2,93 & 7,27 \\
\hline $\mathrm{C}$ & 0,96 & 1,09 & $-2,44$ & 3,99 & 6,43 \\
\hline
\end{tabular}

Az item nehézségét az a képességszint reprezentálja, ahol a diákok által adott helyes válasz valószínüsége 50 százalék (5-7. ábra). Az itemek nehézségi indexeit tekintve nem fedték le a teljes képességskálát. Az itemek nagyrészt 1 logitegységszint alattiak, azaz a magasabb képességü tanulóknak könnyünek számítanak. Az itemek felét az alacsonyabb képességszintü diákok is több mint 50 százalék valószínűség mellett jól oldják meg. A legkönnyebbnek (-2 logitegységszint) és a legnehezebbnek (2 logitegységszint feletti) számító feladatok mindhárom teszttípusban ugyanabból a vizsgált területből származ- 
nak. (Az 1-36 itemek a mentális lexikon fejlettségét vizsgálják, a 37-81 itemek pedig a fonológiai tudatosság területét.) 2 logitegységnyi képességszint felett csak egy-egy item mér pontosan.

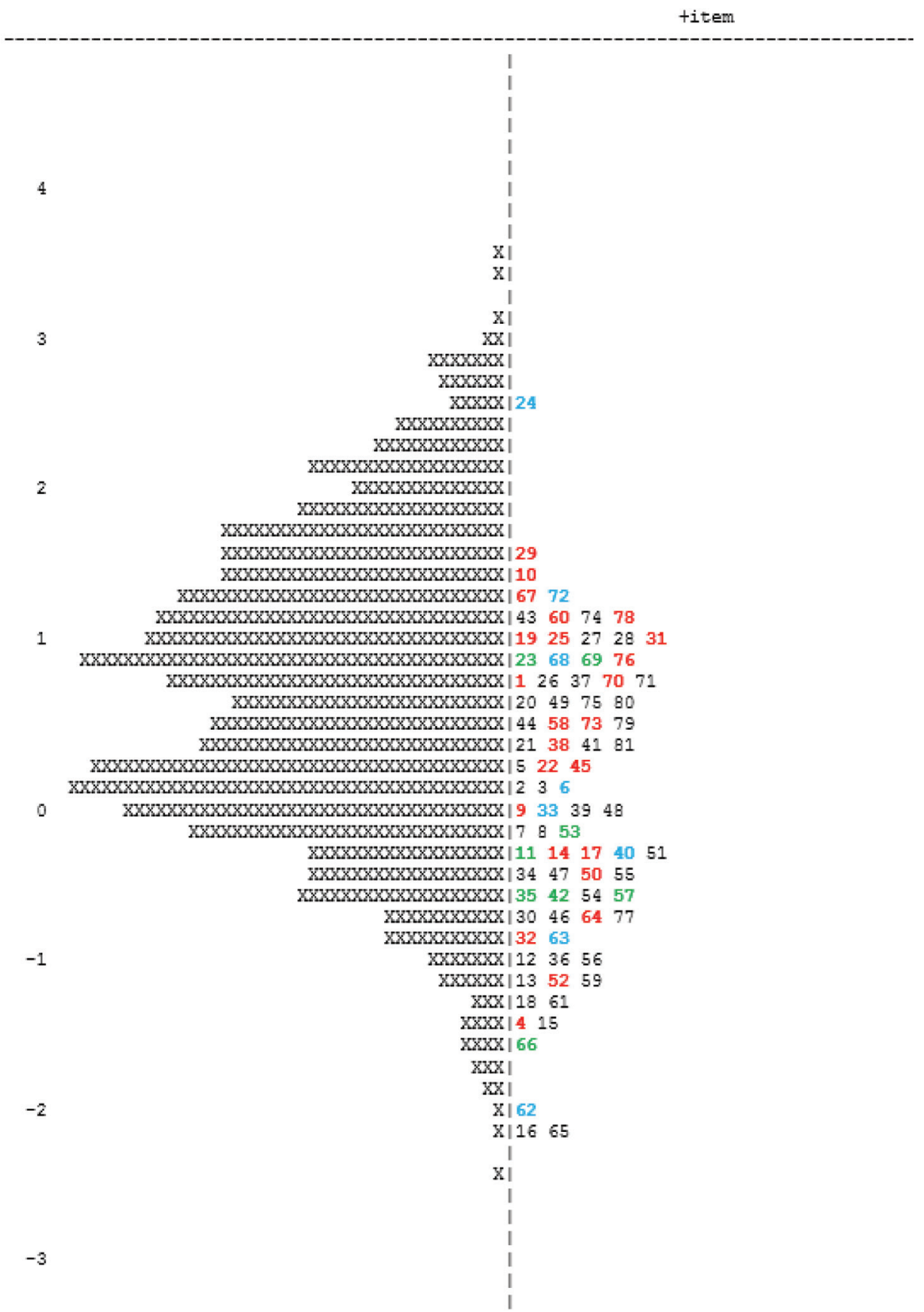

5. ábra. Az A teszt személy/item-térképe (megjegyzés: minden 'x' 0,8 föt reprezentál, piros szín: $A$ - $B$ - $C$ teszt közös horgonyitemek; kék szín: A-B teszt közös horgonyitemek; zöld szín: A-C teszt közös horgonyitemek) 


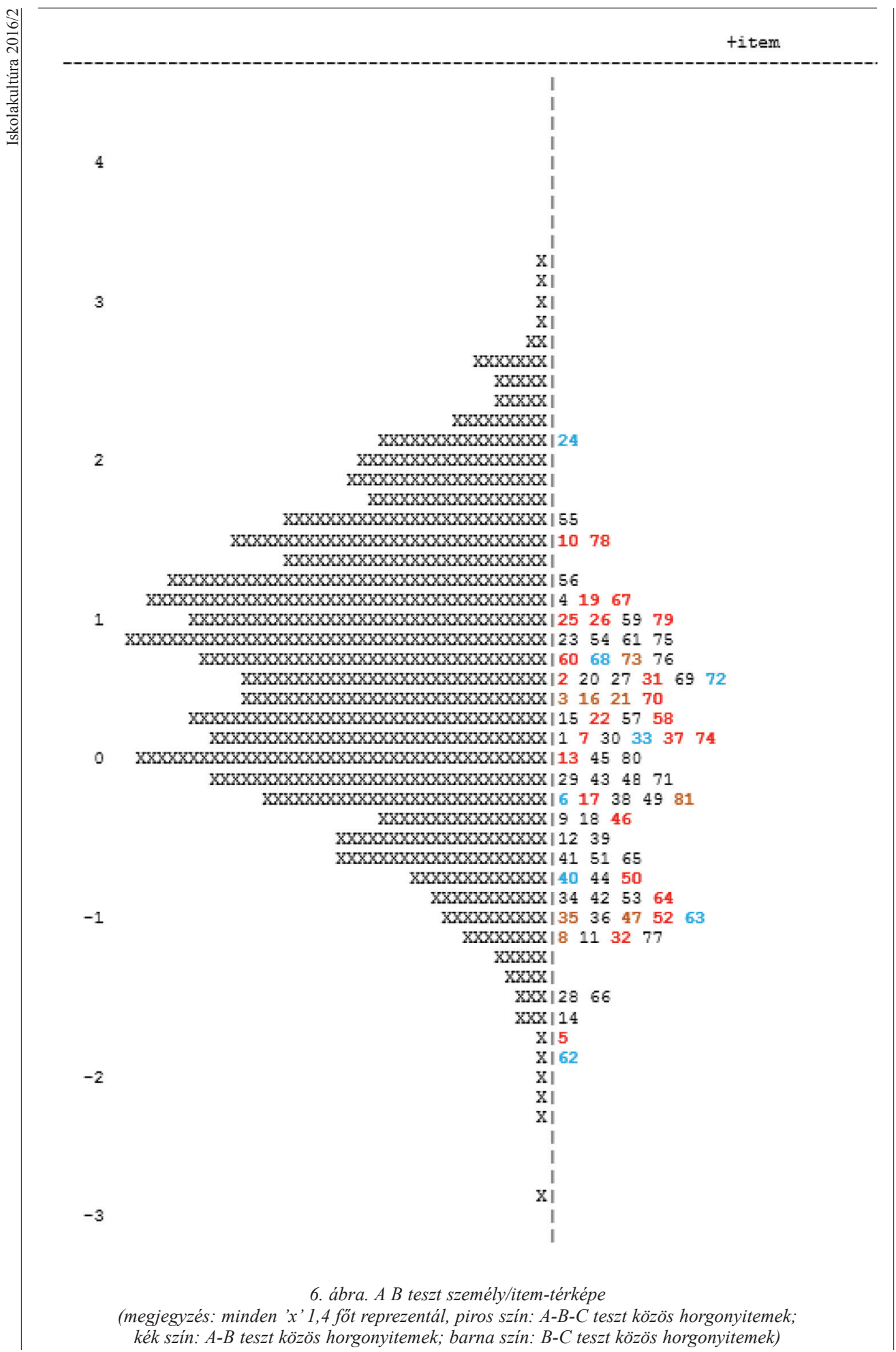


Szili Katalin: A fonológiai tudatosság és a mentális lexikon

4

titem

3

$\operatorname{TXXXXX} \mid 27$

$\operatorname{xxxxxxxx|}$

$\mathrm{xxxxxxx}$

$\mathrm{XXXXXXXXX \times XXX}$

XXXXXXXXXXXXXXXXXX|

$\mathrm{XXXXXXXX \times X \times X \times X \times XX1}$

$\mathrm{Xxxx \times x \times x \times x \times x \times x \times xx|}$

2

$\operatorname{xxxxxx\times xx\times x\times x\times x\times xxx\times x\times x\times x\times xxx} \mid 1077$

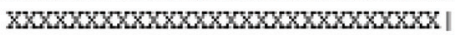

xxxxxxxxxxxxxxxxxxxxxy |

XXXXXXXXXXXXXXXXXXXXXXXXXXXXX||26 37

$\mathrm{xxx \times x \times x \times x \times x \times x \times x \times x \times x \times x \times x \times x \times x \times x \times x \times x|31}$

$\mathrm{XXXXXXXXXXXXXXXXXXXXXXXXXXXXXX|19} 6075$

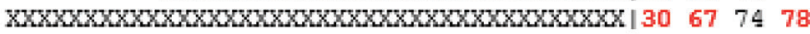

1

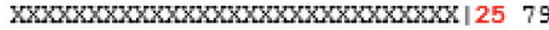

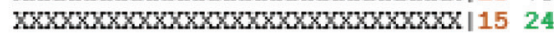

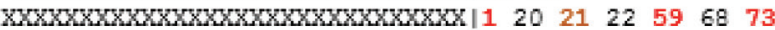

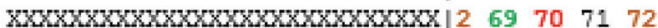

xxxxxxxxxxxxxxxxxxxxxxxxxx|17 $23 \quad 41$

$\operatorname{XXXXXXXXXXXXXXXXXXXXXXXXXXXXXXX|38} 5676$

0

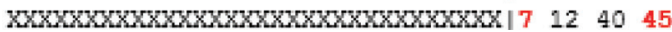

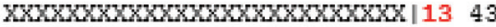

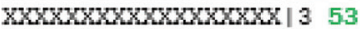

$\begin{array}{llllll}\text { XXXXXXXXXXXXXXXXXXXX|11 } & 39 & 50 & 62 & 80\end{array}$

Xxxxxxxxxxxxxxxxxxxx|28 44

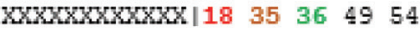

XXXXXXXXXXXXXX|33 55

$\begin{array}{lllllll}\mathrm{XXXXXXXXX|} 14 & 16 & 42 & 48 & 51 & 57 & 81\end{array}$

$-1$

$\mathrm{XXXXXXXXX|8 \quad 47 \quad 63}$

$\mathrm{XXXX} \mid 32 \quad 46 \quad 65$

$\mathrm{XX} \| 52$

$\mathrm{XXX} \mid 434$

$\mathrm{XXX} / 558$

XI9 2966

$\mathrm{X} \mid 61$

$\mathrm{XI}$

$\mathrm{X} \mid 64$

$\mathrm{XI}$

16

$-3$

I

7. ábra. A C teszt személy/item-térképe

(megjegyzés: minden 'x' 0,8 föt reprezentál, piros szin: A-B-C teszt közös horgonyitemek, zöld szín: A-B teszt közös horgonyitemek; barna szín: B-C teszt közös horgonyitemek) 
Az A, B, C teszt személy/item-térképe lehetőséget biztosít a horgonyitemek viselkedésének vizsgálatára (5-7. ábra). Mivel az itemeknek nincsen abszolút nehézségi indexe, ezért a három tesztváltozat horgonyitemeinek külön skálázott konkrét nehézségi indexei nem hasonlíthatók össze. Az összehasonlítás szempontját a személy/item-térképen mutatott feladatnehézségi sorrend adja. A horgonyitemek egymáshoz való viszonya mind a 24 esetben ideális, mivel az adatbázisok alapján felállított nehézségi sorrendjük minimális eltéréssel megegyezik. A minimális eltérést az itemek sorrendjének felcserélődésében tapasztalhatjuk, amelyek kizárólag közel azonos nehézségi szinten lévő itemeknél fordult elő. Ezért tendenciaszinten megállapítható, hogy a horgonyitemek mindhárom mintában azonosan viselkedtek. Az a feladat, ami az egyik minta esetében nehezebbnek bizonyult, a másik minta esetében is hasonlóan viselkedett, azaz alkalmazhatjuk a horgonyitemek segítségével történö összeskálázást, közös skála kialakítását. A kapott eredmények alapján a teljes vizsgált populáció $(\mathrm{A}, \mathrm{B}, \mathrm{C})$ horgonyitemekkel újraskálázott tesztváltozatát egy tesztként értelmezzük.

A három tesztváltozat horgonyitemekkel újraskálázott tesztváltozata sem megbízhatóságában $(0,92)$, sem a tanulói képességeloszlásban $(\mathrm{M}=0,8, \mathrm{SD}=1,04, \min =-4,13$, max $=+3,85)$ nem mutat jelentős eltérést az A, B, C tesztváltozatokhoz képest. Változás az itemek számában tapasztalható, ami a horgonyitemek beillesztése miatt 164 itemre növekedett (8. ábra).

Az A, B, C tesztváltozatokban 24 közös horgonyitem található. A horgonyitemek egymáshoz való viszonya mind a 24 esetben ideális. Az itemek nehézségi sorrendjét összehasonlítva megállapítható, hogy az A, B, C, D adatbázisok (D=horgonyitemekkel újraskálázott) alapján felállított itemnehézségi sorrend minimális eltéréssel mind a négy adatbázisban megegyezik. A sorrend felcserélődése szintén csak a közel azonos nehézségi szinten lévő itemeknél fordult elő. Ezért tendenciaszinten megállapítható, hogy a horgonyitemek mind a négy mintában azonosan viselkedtek, a horgonyitemekkel újraskálázott tesztváltozat alkalmas a teljes minta vizsgálatára. A továbbiakban az itemek viselkedését és a tanulói teljesítményeket az újraskálázott tesztváltozat alapján folytatjuk.

A PtBis indexek alapján megállapítható, hogy mindegyik item megfelelően müködött a tesztben. Ezek az indexek a helyes válasz esetében pozitív előjelüek, azaz az item jól müködik abban az értelemben, hogy akik az adott itemre helyes választ adott, az egész teszten jobb eredményt ért el, mint aki helytelenül válaszolt.

Az itemekhez tartozó elkülönítésmutató nyolc item kivételével 0,2 feletti értéket mutat. Így megállapítható, hogy a nyolc item kivételével az itemek megfelelően különítik el egymástól a különböző képességszintű diákokat.

Az itemnehézségi mutatók tág keretek között mozognak $(-3,107-+2,678)$, amit a 9 . ábra szemléltet. 78 item nehézsége a 0 logitegység alatti tartományba tartozik, azaz alacsonyabb, mint a diákok átlagos képességszintje. Ezeket az itemeket az átlagos képességü tanulók is 50 százaléknál nagyobb eséllyel oldják meg helyesen. Jelen esetben ez azt jelenti, hogy a feladatot megoldó diák a hallott hang(ok), szótag(ok), szavak jelentését megértették, s a hozzá társuló müveleteket már képesek elvégezni. A magasabb képességszint felé való eltolódást ezen itemek helyes megoldása okozza. A fennmaradó 86 item nehézsége a 0 logitegység feletti tartományba tartozik: ezek alkalmasak az átlagos és az átlagosnál magasabb tanulói képességek differenciálására. A teszt megfelelö müködését igazolja, hogy az itemek közel azonos számban differenciálják az átlagosnál alacsonyabb, valamint az átlagosnál magasabb képességszinttel rendelkező diákokat. Az itemek nehézségi indexei alapján tapasztalható, hogy három item kivételével 4 logitegységnyi (-2 logit - +2 logit) értéksávba tartoznak. Egy item túl könnyünek, kettő pedig nehezebbnek bizonyult a vizsgált minta képességparamétereihez viszonyítva. Az itemek sokfélesége is a teszt megfelelö müködését igazolja. A további tesztfejlesztés céljából szükség lenne még nehezebb itemek beillesztésére, hogy a magasabb képességszinttel rendelkező diákokat is megfelelően differenciálja. 
8. ábra. A horgonyitemekkel újraskálázott személy/item térkép (megjegyzés: minden egyes 'x' 2,3 diákot reprezentál; piros szín: A-B-C teszt közös horgonyitemek; kék szín: A-B teszt közös horgonyitemek; barna szín: B-C teszt közös horgonyitemek, zöld szín: A-C teszt közös horgonyitemek) 


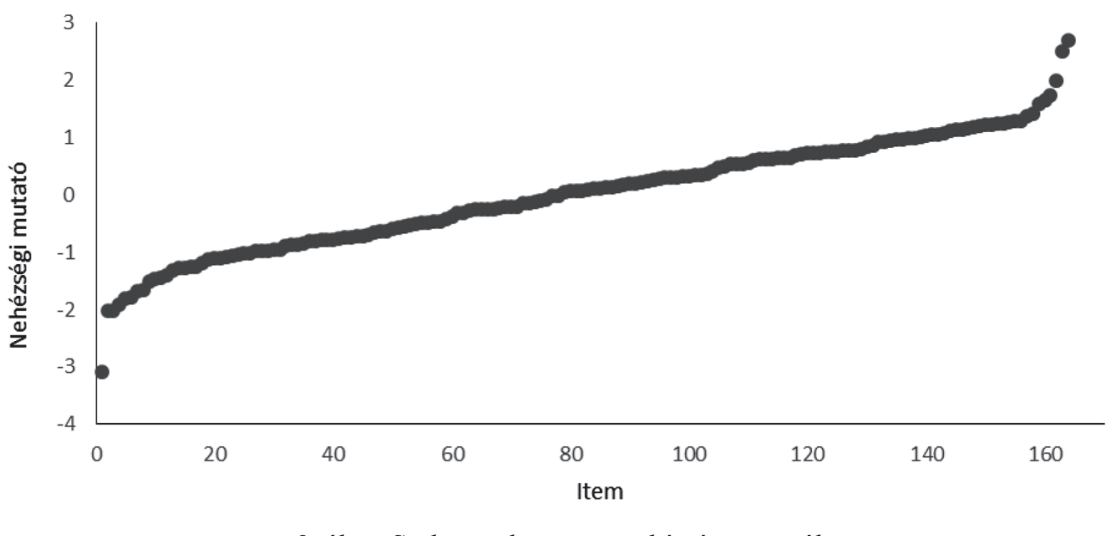

9. ábra. Sorba rendezett itemnehézségi mutatók

„Az item modell-illeszkedése a modell által elvárt, előre jelzett és a valós teljesítmény közötti különbséget mutatja" (Molnár, 2003, 427. o.). Az infit paraméter nagysága megmutatja az itemek modell-illeszkedését. Az item annál jobban illeszkedik a modellhez, minél közelebb van az item infit paramétere - a megadott elfogadási sávon belül $(\mathrm{p}<0,05)$ - az 1-hez. Általánosítva, a jelen mintaméret esetén a 0,70 és a 1,30 közötti értékek fogadhatóak el, az 1,30 felettiek nem illeszkednek, a 0,70 alattiak pedig túlilleszkednek (Molnár, 2003). 1-nél nagyobb érték esetén a modellált görbénél laposabb az item empirikus görbéje, 1-nél kisebb érték esetén pedig meredekebb, ebben az esetben az item jobban differenciálja a különböző képességszintű tanulókat, mint a tesztben lévő jobban illeszkedő itemek (Molnár, 2013).

$\mathrm{Az}$ itemek modellhez való illeszkedését a 10. ábra szemlélteti. 2 item kivételével mindegyik item infit értéke 0,70 és 1,30 közötti. A 164 itemből 98 item az itemkonfidencia-intervallum által meghatározott sávban van, azaz illeszkedik a modellhez. 5 item tökéletesen illeszkedik, 70 item pedig 0,1 értékkel tér el a modell által meghatározott 1 értéktől. A 98 item közül 90 item infit értékéhez tartozó t érték a 0 értéktől nem tér el jelentősen ( $-1,1$ és $+1,2$ közötti értéküek), azonban 8 item esetében a t értéke nagymértékben eltér a várható 0 értéktől, ezért ezen itemek felülvizsgálata szükséges.

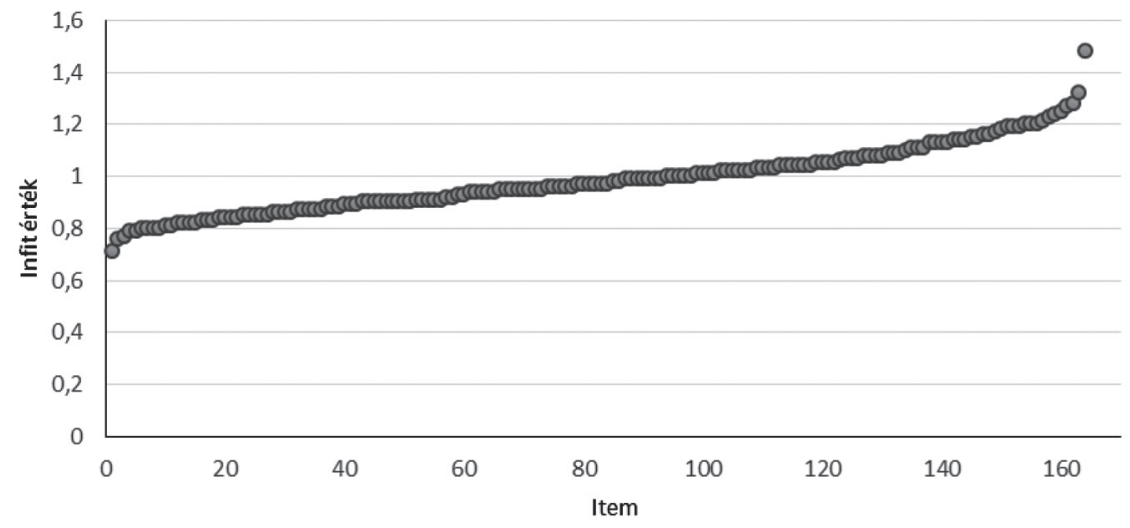

10. ábra. Az itemek modell-illeszkedése 
Diákonkénti bontásban a mérési hibák összehasonlítása alapján megállapítható, hogy a teszt az elvárásnak megfelelően müködik (11. ábra). Az átlagos képességtartománytól távolodva a mérési hibák nagysága növekszik. A teszt legalacsonyabb mérési hibával a -2 és a +2 képesség tartományban mér, amely tartományba a vizsgált minta jelentős része tartozik.

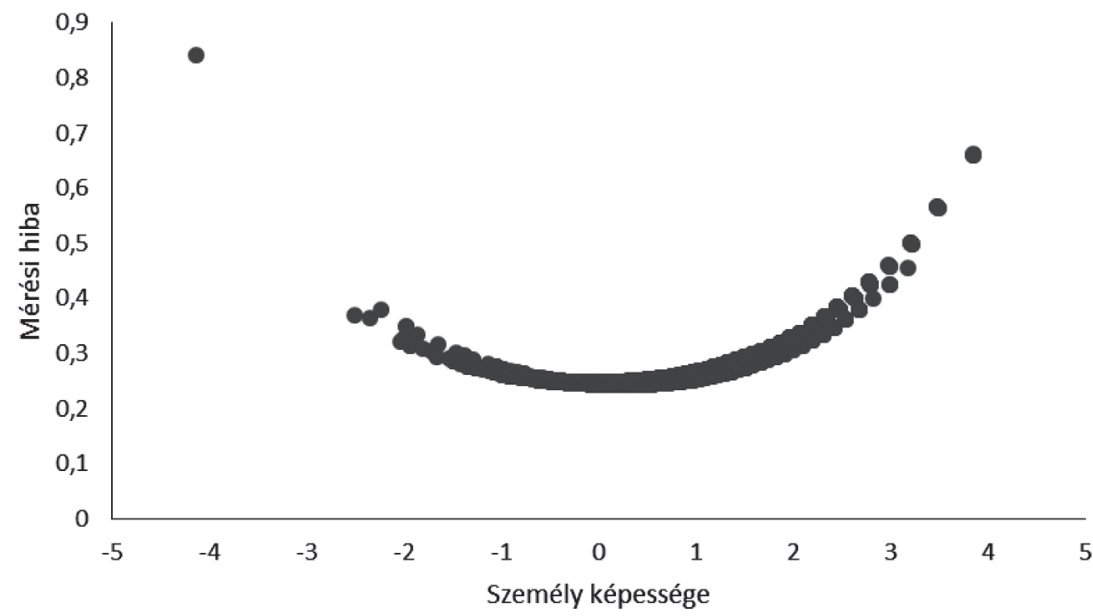

11. ábra. A mérési hiba alakulása a tanulók képességszintjének függvényében

A valószínüségi tesztelméleti elemzések is lehetőséget biztosítanak a teszten belüli többdimenziós vizsgálatokra. A két dimenzió EAP/PV reliabilitás-mutatója megfelel az elvárt értékeknek. Ez az érték a mentális lexikon dimenzió esetében alacsonyabb $(0,87)$, mint a fonológiai tudatosság dimenzió esetében $(0,91)$. A minta empirikus populáció paramétere eltérő a két dimenzióban. A mentális lexikon területét vizsgáló feladatok megoldásához 2 logitegységnél alacsonyabb képességparaméter $(0,79)$ szükséges, mint a fonológiai tudatosság területét vizsgáló feladatok esetében (3,00). A két dimenzió között erős összefüggés tapasztalható $(\mathrm{r}=0,89)$. A két dimenzió személy/item-térképét ábrázolja a 11. ábra. A minta eloszlása mindkét dimenzióban hasonló, a normál eloszlást közelíti. A fonológiai tudatosság fejlettségét vizsgáló itemek megoldásához legalább 0 képességszinttel kell rendelkeznie a diákoknak, ez 2 logitegységgel több, mint a mentális lexikon dimenzióját vizsgáló itemek megoldásához szükséges paraméter. A mentális lexikon dimenziójába tartozó itemek szinte teljesen lefedik a saját dimenziójának tanulói képességeloszlását, a fonológiai tudatosság dimenziójához tartozó itemek a nagyon magas - a 4 logitegységnél magasabb - képességszintü diákok számára nem tartalmaznak feladatokat. 


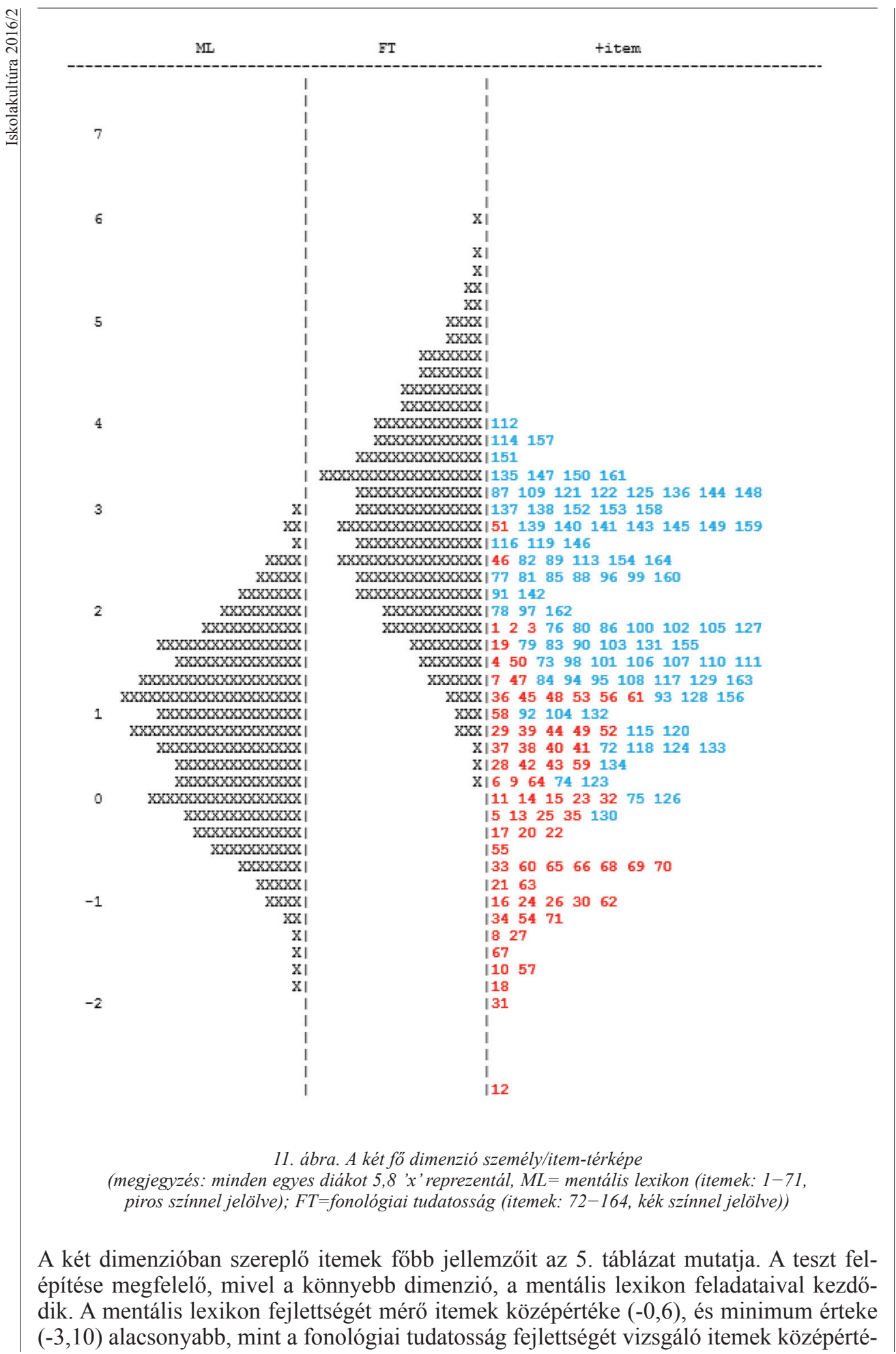


ke $(0,04)$ és minimumértéke $(-1,91)$. Az első dimenzió belső stabilitásának javítása szükséges, mivel az itemek nehézségi indexei tág határok között mozognak, a skálaterjedelem meghaladja az 5 logitegységnyit. Ennek feltehetően az a három túl könnyü item az oka, amelyeknek -2 logitegység, illetve ennél kevesebb az item nehézségi mutatójuk.

5. táblázat. A feladatok nehézségi indexeinek föbb jellemzői a két dimenzióban

\begin{tabular}{|l|c|c|c|c|c|c|}
\hline \multirow{2}{*}{ Dimenzió } & \multirow{2}{*}{$\begin{array}{c}\text { Itemek } \\
\text { száma }\end{array}$} & \multicolumn{2}{|c|}{ Skála logitok } & \multirow{2}{*}{$\begin{array}{c}\text { Középérték } \\
\text { logitok }\end{array}$} & $\begin{array}{c}\text { Skála terje- } \\
\text { delme }\end{array}$ & Szórás \\
\cline { 3 - 4 } & & Minimum & Maximum & & 1,08 \\
\hline Mentális lexikon & 71 & $-3,10$ & 2,67 & $-0,6$ & 5,78 & 0,88 \\
\hline Fonológiai tudatosság & 93 & $-1,91$ & 1,97 & 0,04 & 3,89 & 0,89 \\
\hline
\end{tabular}

\section{Az eredmények értelmezése}

A kutatási eredmények alapján kijelenhető, hogy a teszt megbízhatóan müködik. A mérőeszközt alkotó három tesztváltozatot külön-külön is megvizsgáltuk annak érdekében, hogy megbizonyosodjunk arról, hogy a tesztek hasonlóan müködnek-e. Mindhárom mérőeszköz WLE személyszeparációs reliabilitásmutatója magas. A helyes müködést a tesztekben alkalmazott páronkénti horgonyitemek összehasonlításával végeztük, s az eredmények azt mutatták, hogy mindegyik item azonos nehézségi tartományban helyezkedett el, pozíciójuk és itemnehézségi fokuk minimális mozgást mutatatott. Ezek után megvizsgáltuk a horgonyitemekkel újraskálázott mérőeszközt, amelynek reliabilitása a három tesztváltozatéhoz hasonlóan magas értékeket mutatott. Az erős horgonyzást biztosító itemek mindegyik tesztváltozatban hasonló pozícióban helyezkedtek el, itemnehézségi indexük minimális eltérést mutatott. A feladatok nehézségi indexei lefedték a populáció nagy részét. Azonban a magasabb képességparaméterrel rendelkező tanulók differenciálására csak kevés item volt alkalmas. A tesztfejlesztés szempontjából megvizsgáltuk mindegyik dimenzió itemeinek nehézségét a tanulói képességek fényében. A kapott eredmények alapján megállapítottuk, hogy a mentális lexikon szubteszt könnyebb volt a diákok számára, mint a fonológiai tudatosság szubteszt.

A kutatás gyakorlati jelentősége, hogy a tesztfejlesztés során olyan mérőeszközt sikerült kialakítanunk, ami megbízhatóan alkalmazható osztálytermi környezetben.

A kutatás gyakorlati jelentósége, hogy a tesztfejlesztés során olyan méróeszközt sikerült kialakítanunk, ami megbizhatóan alkalmazható osztálytermi környezetben. A méróeszköz alkalmas olyan területek mérésére, amelyek a hazai gyakorlatba még nem integrálódtak be szervesen. A számítógépes környezet ezt nagymértékben elósegítheti, mivel a mérés lebonyolítása egyszerú, nem igényel speciális ismereteket a tesztfelvételi eljárással és az adatrögzitéssel kapcsolatban, hiszen minden automatikusan müködik. A mérőeszköz alkalmas olyan területek mérésére, amelyek a hazai gyakorlatba még nem integrálódtak be szervesen. A számítógépes környezet ezt nagymértékben elösegítheti, mivel a mérés lebonyolítása egyszerü, nem igényel speciális ismereteket a tesztfelvételi eljárással és az adatrögzítéssel kapcsolatban, hiszen minden automatikusan 
müködik. A tesztfelvétel nincsen szigorú időhöz kötve, a tanév, s a nap bármely szakaszában felvehető. Az azonnali visszacsatolás miatt elegendő egy tanórányi egység, hogy a diákok képességét megismerje a pedagógus és természetesen a tanuló saját maga is. A teszt a tanév alatt többször is kitölthető, amivel biztosítható válik a tanulói képességfejlődések egyszerü nyomon követése. Három azonos nehézségü tesztváltozatból épül fel a méröeszköz, ezért elkerülhető, hogy az egymás mellett ülő diákok ugyanazokat a feladatokat oldják meg, kiküszöbölve ezzel az egymásnak való segítségnyújtást. A tesztváltozatok lehetőséget biztosítanak arra is, hogy a többszöri kitöltés során a diákok ne ugyanazzal a teszttel találkozzanak. A tanulók képessége pontosabban megbecsülhető, ami a kritériumorientált fejlesztés alapja.

A kutatás egyedisége egyrészt abban nyilvánul meg, hogy a fonológiai tudatosság és a mentális lexikon fejlettségét egy teszten belül vizsgálja, egyszerre tizenhárom területen. Ilyen mértékü komplexitás kevés vizsgálóeljárásban tapasztalható. Másrészt a hazai pedagógiai mérések során az általunk vizsgált területek számítógép-alapú komplex vizsgálata még nem valósult meg. Nemzetközi viszonylatban is csak egy-egy mérőeszköz készült. A mérésekben 1-3. évfolyamos tanulók vettek részt, s a mérési eredmények alapján megállapítható, hogy a teszt tág életkori határok között is megbízhatóan mér. A kutatási eredmények általánosíthatóságának korlátai között szerepel, hogy egyes feladatok típusán változtatnunk kellett a technológiai korlátok miatt. Az önálló megnevezést igénylő feladatok esetében az alternatív választáson alapuló feladattípust alkalmaztuk.

\section{Irodalomjegyzék}

Bowers, L., Huisingh, R., LoGiudice, C. és Orman, J. (2014): The WORD test 3 elementary. A test of expressive vocabulary and semantics. Examiner's Manual. LinguaSystems Inc.

Csapó Benő és Csépe Valéria (2012): Bevezetés. In: Csapó Benő és Csépe Valéria (szerk.): Tartalmi keretek az olvasás diagnosztikus értékeléséhez. Nemzeti Tankönyvkiadó, Budapest. 9-16.

Csapó Benő, Molnár Gyöngyvér és R. Tóth Krisztina (2008): A papíralapú tesztektől a számítógépes adaptív tesztelésig. Iskolakultúra, 18. 3-4. sz. 3-16.

Csapó Benő, Molnár Gyöngyvér, Pap-Szigeti Róbert és R. Tóth Krisztina (2009): A mérés-értékelés új tendenciái, a papír alapú teszteléstől az online tesztelésig. In: Kozma Tamás és Perjés István (szerk.): $U j$ kutatások a neveléstudományokban. Hatékony tudomány, pedagógiai kultúra, sikeres iskola. Magyar Tudományos Akadémia, Budapest. 99-108.

Csapó, B., Molnár, Gy. és Nagy, J. (2014): Computerbased assessment of school readiness and early reasoning. Journal of Educational Psychology, 106. 2. sz. 639-650. DOI: 10.1037/a0035756

Csépe Valéria és Tóth Dénes (2008): Az olvasás fejlődése kognitív pszichológiai nézőpontból. Pszichológia, 28. 1. sz. 35-52. DOI: 10.1556/pszi.28.2008.1.3

Domino, G. és Domino, M. L. (2006): Psychological testing: An introduction. 2. kiadás. Cambridge Publishing, New York. DOI: 10.1017/cbo9780511813757
Goswami, U. (2006): Phonology, learning to read and dyslexia: A cross-linguistic analysis. In: Csépe Valéria (szerk.): Different brain, different behavior. Kluwer Academic, New York. 1-40.

Jansen, H., Manhaupt, G., Marx, H. és Skowronek, H. (1999): Bielefelder Screening zur Früherkennung von Lese-Rechtschreibschwierigkeiten (BISC). Hogrefe, Bern.

Jordanidisz Ágnes (2009): A fonológiai tudatosság fejlődése az olvasástanulás időszakában. Anyanyelvpedagógia, 4. 2013. 11. 10-i megtekintés, http:// www.anyanyelv-pedagogia.hu/cikkek.php?id=222

Konza, D. (2011): Phonological awareness. Research into practice. Understanding the reading process. Kézirat. 2014. 11. 20-i megtekintés, http://speldnsw. org.au/wp-content/uploads/2015/09/1.6-comprehension.pdf

Lőrik József és Májercsik Edit (2015): Iskolába lépó és 1. osztályos gyermekek néhány olvasási-irási alapkészségének vizsgálata. Tesztfelvételi, pontozási és értékelési útmutató. Educatio Társadalmi Szolgáltató Nonprofit Kft., Budapest.

Lukács Ágnes, Pléh Csaba, Kas Bence és Thuma Orsolya (2014): A szavak mentális reprezentációja és az alaktani feldolgozás. In: Pléh Csaba és Lukács Ágnes (szerk.): Pszicholingvisztika 1. Magyar pszicholingvisztikai kézikönyv. Akadémia Kiadó. Budapest. 167-250.

Maguire, K. B., Knobel, M., L. M., Knobel, B. L., Sedlacek, L. G. és Piersel, W. C. (1991): Computer- 
Szili Katalin: A fonológiai tudatosság és a mentális lexikon

adapted PPVT-R: A comparison between standard and modified versions within an elementary school population. Psychology in the Schools, 28. 3. sz. 199-205.

DOI: 10.1002/1520-6807(199107)28:3<199::aidpits2310280303>3.0.co;2-Z

Magyar Andrea és Molnár Gyöngyvér (2015): A szóolvasási készség online adaptív mérésének hatékonyságvizsgálata. Magyar Pedagógia, 115. 4. sz. DOI: 10.17670/mped.2015.4.403

Molnár Éva és B. Németh Mária (2006): Az olvasásképesség fejlettsége az iskoláskor elején. In: Józsa Krisztián (szerk.): Az olvasási képesség fejlödése és fejlesztése. Dinasztia Tankönyvkiadó, Budapest. 107-131.

Molnár Gyöngyvér (2003): Az ismeretek alkalmazásának vizsgálata modern tesztelméleti (IRT) eszközökkel. Magyar Pedagógia, 103. 4. sz. 423-446.

Molnár Gyöngyvér (2013): A Rasch modell alkalmazási lehetöségei az empirikus kutatások gyakorlatában. Gondolat Kiadó, Budapest.

Molnár Gyöngyvér (2015a): A képességmérés dilemmái: a diagnosztikus mérések (eDia) szerepe és helye a magyar közoktatásban. Géniusz Mühely Kiadványok, 2. sz. 16-29. 2015. 10. 10-i megtekintés, http:// tehetseg.hu/sites/default/files/mentorok_es mentoraltak/nwp15.pdf

Molnár Gyöngyvér (2015b): Az óvoda és iskola feladatai az értelmi képességek fejlesztése terén. In: Kónyáné Tóth Mária és Molnár Csaba (szerk.): Tartalmi és szervezeti változások a köznevelésben. Suliszerviz Oktatási és Szakértői Iroda, Suliszerviz Pedagógiai Intézet, Debrecen. 179-190.

Molnár Gyöngyvér és Csapó Benő (2013): Az eDia online diagnosztikus mérési rendszer. Előadás: XI. Pedagógiai Értékelési Konferencia, Szeged, 2012. április $11-13.82$.

Molnár Gyöngyvér és Magyar Andrea (2015): A számítógép alapú tesztelés elfogadottsága pedagógusok és diákok körében. Magyar Pedagógia, 115. 1. sz. 49-66. DOI: 10.17670/mped.2015.1.47

Molnár Gyöngyvér és Pásztor-Kovács Anita (2015): A számítógépes vizsgáztatás infrastrukturális kérdései: az iskolák eszközparkjának helyzete és a változás tendenciái. Iskolakultúra, 25. 4. sz. 49-61. DOI: 10.17543/iskkult.2015.4.49

Mullis, I. V. S. és Martin, M. O. (szerk.): PIRLS 2016 Assessment framework. 2. kiadás. TIMSS \& PIRLS International Study Center, Boston College, Chestnut Hill, MA.

Nagy József (2004): A szóolvasó készség fejlődésének kritériumorientált diagnosztikus feltérképezése. Magyar Pedagógia, 104. 2. sz. 123-142.
Nagy József, Fazekasné Fenyvesi Margit, Józsa Krisztián és Vidákovich Tibor (2002): DIFER Diagnosztikus fejlödésvizsgáló rendszer. OKÉV, KÁOKSZI, Budapest.

Salthouse, T. A. (1993): Speed and knowledge as determinants of adult age differences in verbal tasks. Journal of Gerontology: Psychological Sciences, 48 1. sz. 29-36. DOI: 10.1093/geronj/48.1.p29

Singleton, C. H. (1997): Screening for early literacy. In: Beech, J. és Singleton, C. H. (szerk.): The psychological assessment of reading. Routledge, London. 67-101.

Singleton, C. H., Thomas, K. V. és Leedale, R. C. (1996): Lucid cognitive profiling system (CoPS). Lucid Research, Beverley.

Steklács János (2014): A szemmozgás vizsgálatának lehetôségei az olvasás és a vizuális információfeldolgozás képességének a megismerésében. Anyanyelvpedagógia, 7. 6. sz. 2015.01.07-i megtekintés, www. anyanyelv-pedagogia.hu

Szili Katalin (2013): Comparison of paper - and computer based testing among primary school children. Előadás: IRI Educational Conference, Komarno, 2013. június 20-22.

Szili Katalin és Pásztor Attila (2013): A beszédpercepció online mérése 1-3. osztályos tanulók körében. Előadás: Pedagógiai Értékelési Konferencia, Szeged, április 12 .

Torgesen, J. K. és Bryant, B. (1994): Test of Phonological Awareness. Pro-Ed, Austin, TX.

Tóth Edit, Molnár Gyöngyvér és Csapó Benő (2011): Az iskolák IKT felszereltsége - helyzetkép országos reprezentatív minta alapján. Iskolakultúra, 21. 10-11. sz. 124-137.

Wagner, R. K., Torgesen, J. K. és Rashotte, C. A. (1999): Comprehensive test of phonological processing. PRO-ED, Austin, TX.

Wang, S., Jiao, H., Young, M. J., Brooks, T. és Olson, J. (2008): Comparability of computer based and paper-and-pencil testing in K-12 reading assessment; a meta-analysis of testing mode effects. Education and Psychological Measurement, 68. 5. sz. 5-24. DOI: $10.1177 / 0013164407305592$

Wilson, S. L., Thompson, J. A. és Wylie, G. (1982): Automated psychological testing for the severely physically handicapped. International Journal of Man-Machine Studies, 17. 6. sz. 291-296. DOI: 10.1016/s0020-7373(82)80029-1 